www.jmscr.igmpublication.org

Impact Factor 5.244

Index Copernicus Value: 83.27

ISSN (e)-2347-176x ISSN (p) 2455-0450

crossref DOI: _https://dx.doi.org/10.18535/jmscr/v4i10.73

\title{
Pattern of Peptic Perforation at VSS IMSAR, Burla- Retrospective Study of 100 Cases
}

\author{
Authors \\ Dr Banabihari Mishra ${ }^{1}$, Dr Bhupesh Kumar Nayak $^{2}$, Dr Kishan Bhoi ${ }^{3}$ \\ ${ }^{1}$ Asso. Prof., Department of General Surgery, VSS IMSAR, Burla, Sambalpur, Odisha, India \\ ${ }^{2,3}$ Senior Resident, Department of General Surgery, VSS IMSAR, Burla, Sambalpur, Odisha, India \\ Email:eco2box@gmail.com, Contact Number-9437170120
}

\begin{abstract}
Acute peptic perforation may occur in gastric \& duodenal ulcers. Proton pump inhibitors, H2 blockers, $H$ pylori eradication therapy has still not slowed down the incidence of Acute peptic perforation. In emergency gastric surgery, Acute peptic perforation is still the most common emergency surgery associated with high mortality \& morbidity. In emergency acute peptic perforation were diagnosed by the gas under diaphragm in $x$-ray abdomen in straight erect posture \& obliteration of liver dullness. The main surgical treatment was simple closure with grahams patch. Data was collected on various variables such as age group, sex, blood group , seasonal occurrence ,dietary habits, drug history, lifestyle history, prior diagnosis to surgery, findings on admission/per operative findings, methods of operation, complications. A clinical pattern of peptic perforation was carried out at emergency of the department of general \& laparoscopic, surgery, VSSIMSAR, Burla, Odisha between 2012 \& 2016 july.
\end{abstract}

\section{INTRODUCTION}

"Lord moynihan has stated that perforation of duodenal or gastric ulcer is one of the most serious \& overwhelming catastrophes than can befall a human being".

Peptic perforation is an emergency situation to be dealt with utmost urgency. It occurs in 5-10\% of patients presenting with a duodenal ulcer. Peritonitis caused by a perforated ulcer represents $3 \%$ of all abdominal emergencies.

The mortality rate when operation is performed within 6 hrs of onset of pain approches zero, from $6-12 \mathrm{hrs}$ the rate is $5-10 \%, 12-24 \mathrm{hrs}$ it is $25 \%$ or higher $\&$ in the course of $3^{\text {rd }}$ day after, operations are seldom successful $\&$ is acheived only by prompt healthcare from a qualified professional.

\section{AIMS \& OBJECTIVES}

1. To study the pattern of peptic ulcer perforation in VSSIMSAR, Burla.

2. To study the course of treatment, follow up period, complications mortality, morbidity of the disease.

\section{INCLUSION CRITERIA}

Any patient presenting to emergency with history of pain abdomen, distension of abdomen, presence of gas under diaphragm with $\mathrm{x}$-ray abdomen erect $\&$ obliteration of liver dullness.

\section{EXCLUSION CRITERIA}

Patient with $\mathrm{X}$-ray finding not attributable to gas under diaphragm were excluded from this group. 


\section{MATERIALS \& METHODS}

The study covers 100 patients treated in the emergency in Dept. of general \& laparoscopic surgery VSSIMSAR from 2013 To 2016 july

We collected data from bed tickets, regarding presentation, investigations, surgical procedures done, complications, follow up \& entered into a standard format \& processing was done using Microsoft excel.

\section{OBSERVATION}

\section{CLINICAL FEATURES}

1. PAIN ABDOMEN-sudden \& agonizing pain in upper abdomen radiating to shoulder tip.

2. VOMITTING \& NAUSEA-more than 70 $\%$ patients complained of vomiting \& less than $20 \%$ were having nausea at the time of admission.

3. HAEMORRHAGE-association with perforation is a grave complication.

SIGN

1. ABDOMINAL RIGIDITY \& TENDERNESS - was observed in all cases.

2. OBLITERATION OF LIVER DULLNESS- due to collection of free air under the diaphragm.70 \% of the patients were having obliteration of liver dullness.

3. BOWEL SOUNDS- in $80 \%$ cases bowel sounds were absent, $1 \mathrm{n} 10 \%$ bowel sound were diminished .

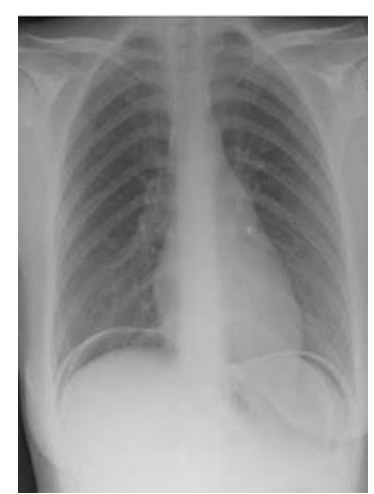

X-ray abdomen straight erect showing free Gas under both domes of diaphragm.
Table 1-Age of Incidence

\begin{tabular}{|c|c|c|}
\hline AGE GROUP & NO OF CASES & $\%$ \\
\hline $0-20$ & 2 & 2 \\
\hline $20-40$ & 20 & 20 \\
\hline $40-60$ & 55 & 55 \\
\hline$>60$ & 28 & 28 \\
\hline
\end{tabular}

Peak incidence of peptic perforation was noted in the 40-60 age group with $55 \%$ occurrence. the youngest patient is 16 years old and oldest 83 year

Table -2 -Incidence Related To Blood Group

\begin{tabular}{|c|c|c|}
\hline Blood Group & No Of Cases & $\%$ \\
\hline $\mathrm{O}$ & 45 & 65 \\
\hline $\mathrm{A}$ & 23 & 23 \\
\hline $\mathrm{B}$ & 20 & 20 \\
\hline $\mathrm{Ab}$ & 12 & 12 \\
\hline
\end{tabular}

O group patients with perforation was common in the study with $45 \%$

Table-3 Sex Wise Distribution Of Patient

\begin{tabular}{|c|c|c|}
\hline YEAR & $\begin{array}{c}\text { MALE } \\
\text { (\% of patients) }\end{array}$ & $\begin{array}{c}\text { FEMALE } \\
\text { (\% of patients })\end{array}$ \\
\hline $\begin{array}{c}2013 \text { to } 2016 \\
\text { July }\end{array}$ & 85 & 15 \\
\hline
\end{tabular}

PEPTIC PERFORATION WAS MORE COMMON IN MALES THAN FEMALES .THIS CAN BE ATTRIBUTED to anxiety, stress, strain, indulgence to smoking, alcoholism, drugs, irregular dietary habit

Table 1 size of perforation

\begin{tabular}{|l|c|c|c|c|}
\hline Size of perforation & $\begin{array}{c}\text { Gastri } \\
\text { c ulcer }\end{array}$ & $\begin{array}{c}\text { Duodenal } \\
\text { ulcer }\end{array}$ & Total & $\%$ \\
\hline Small $(<3 \mathrm{~mm})$ & 3 & 27 & 30 & 30 \\
\hline Medium $(4-6 \mathrm{~mm})$ & 5 & 45 & 50 & 50 \\
\hline large $(7-10 \mathrm{~mm})$ & 1 & 11 & 12 & 12 \\
\hline Very large $>10 \mathrm{~mm}$ & 2 & 6 & 8 & 8 \\
\hline
\end{tabular}

In our study, over $80 \%$ of cases had small \& medium perforations, large in 12.I, $8 \%$ cases were very large perforations.

$11 \%$ cases were gastric ulcer perforations. their margins were sent for histopathology study. $89 \%$ cases were duodenal ulcer perforations. 


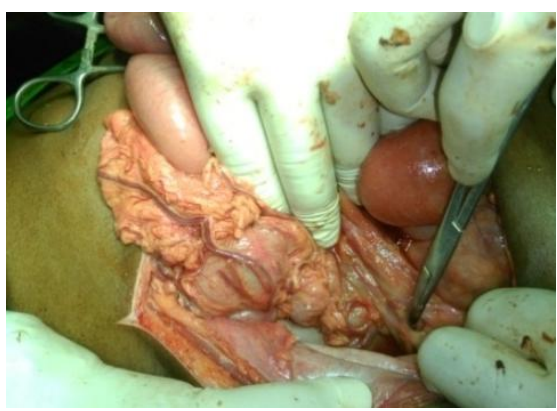

Table-4 type of peritoneal fluid

\begin{tabular}{|l|c|c|}
\hline $\begin{array}{l}\text { Peritoneal fluid types } \\
\text { found per operative }\end{array}$ & cases & $\%$ \\
\hline Bile stained & 40 & 40 \\
\hline turbid & 35 & 35 \\
\hline purulent & 25 & 25 \\
\hline
\end{tabular}

$40 \%$ were found to be having biliary peritonitis. Purulent peritonitis were of late presentation variety with poor eneral condition

Table 2 Surgical treatment of peptic perforation

\begin{tabular}{|l|c|c|c|}
\hline Operation type & $\begin{array}{c}\text { Gastric ulcer } \\
\text { perforated }\end{array}$ & $\begin{array}{c}\text { Duodenal } \\
\text { ulcer } \\
\text { perforated }\end{array}$ & Total \\
\hline $\begin{array}{l}\text { Simple closure with } \\
\text { grahams patch }\end{array}$ & 14 & 80 & 94 \\
\hline $\begin{array}{l}\text { Ulcer excision with } \\
\text { vagotomy } \\
\text { Pyloropasty }\end{array} \quad$ nil & nil & nil \\
\hline Flank drain & 2 & 4 & 6 \\
\hline
\end{tabular}

Simple closure of perforation and grahams patch was done in 94 No of patients

Definitive surgery that is truncal vagotomy \& gastro jejunostomy wa not done as all were emergency cases.

Flank drain under local anaesthesia were given under local anaesthesia in 6 no of patients treated conservatively to be operated later , 2 survived,4 died.

Table - 3 Seasonal Occurrence of Peptic Perforation

\begin{tabular}{|l|l|}
\hline Months & $\%$ of patients \\
\hline January - March & 23 \\
\hline April - June & 15 \\
\hline July - September & 16 \\
\hline October - December & 46 \\
\hline
\end{tabular}

Perforations were found to be more common in winter season in this study
Table -5

\begin{tabular}{|l|c|c|}
\hline Occupation & No. of patients & Percentage \\
\hline Farmer,manual labourer & 70 & 70 \\
\hline Drivers & 5 & 5 \\
\hline Government officials & 3 & 3 \\
\hline Students & 6 & 6 \\
\hline others & 16 & 16 \\
\hline
\end{tabular}

$70 \%$ of farmers \& manual labourers were the worst sufferers owing to irregular diet habit \& alcoholism

Table -6

\begin{tabular}{|l|l|}
\hline $\begin{array}{l}\text { History of dyspepsia/ Peptic } \\
\text { ulcer disease }\end{array}$ & Incidence \\
\hline Yes & 80 \\
\hline No & 20 \\
\hline
\end{tabular}

Table 7

\begin{tabular}{|l|c|c|}
\hline Habits & No. of Patients & Percentage \\
\hline Smoker & 20 & 20 \\
\hline Alchoholic & 15 & 15 \\
\hline Both & 15 & 15 \\
\hline nil & 50 & 50 \\
\hline
\end{tabular}

$15 \%$ of patients were found to be alcoholic .15 $\%$ of patients were found to be both alcoholic and smoker

Table -8 Complications

\begin{tabular}{|l|c|c|}
\hline Complications & no of patients & $\%$ \\
\hline $\begin{array}{l}\text { CHEST } \\
\text { INFECTION/PNEUMONIA/A } \\
\text { RDS }\end{array}$ & 12 & 12 \\
\hline $\begin{array}{l}\text { ABSCESS (PELVIC+ SUB } \\
\text { PHRENIC) }\end{array}$ & 6 & 6 \\
\hline SEPSIS & 17 & 17 \\
\hline WOUND INFECTION & 35 & 35 \\
\hline DUODENAL FISTULAE & 2 & 2 \\
\hline DEATH & 4 & 4 \\
\hline
\end{tabular}

Most common complication were wound infection. they were noted in $35 \%$ of patients. they were drained in early post operative period.

Wound dehiscence occurred in 15 no of patients $\&$ they required secondary suturing.

Sub phrenic abscess were found in 6 no of patients. pelvic abscess were found i 6 no of patients. fever \& mucous diarrohea occurred in late post operative period those were drained immediately. 
Duodenal leak occurred in 2 no of cases and were managed conservatively

Death occurred in 8 no of patients

\section{CONCLUSION}

Duodenal ulcer perforation is the second most common abdominal emergency In our study. Despite all medical measures present elective surgery for peptic perforation is decreasing but the incidence of perforation is unchanged

Most of the patients were middle aged males of low socio economic status .this can be explained to irregular dietary habit, over the counter use of drugs -NSAIDS/STEROIDS in ayurvedic preparation.

In our series all cases are managed by omental patch and no definitive surgery were attempted due to low general conditions of the patients.

In most of our follow up patients they have not needed any revision surgery. all pelvic abscess were treated conservatively except 1 who needed a per rectal drainage .2 leaks in the post operative period were managed conservatively and healed spontaneously.

\section{REFERENCE}

1. MiCHELET I., AGRESTA F. Perforated peptic ulcer : laproscopic approach. Eur $J$ Surg, $166: 405-8$.

2. NAESGAARD J. M., EDWIN B., REFIERTSEN O., TRONDSEN E., PAERDEN A. E., ROSSELAND A. R. Laparoscopic and open operation in patients with perforated peptic ulcer. Eur J Surg, 1999, 165 : 209-14.

3. LORAND I., MOLINER N., SALES J. P., DOUCHEZ F., GAYRAL F. Resultats du traitement coelioscopique des ulceres perfores. Chirugie, 1999, 124 : 149-53.

4. MOURET P., FRANCOIS Y., VIGNAL J., BARTH X., LOMBARD-PLATET R. Laparoscopic treatment of perforated peptic ulcer. Br J Surg, 1990, 77 : 1006.

5. LEE F. Y.J., LEUNG K. L., LAI B. S.P., MAN NG S.S., DEXSTER S., LAU W.Y.
Predicting mortality and morbidity of patients operated on for perforated peptic ulcers. Arch Surg, Arch Surg, 2001, 136 : 90-3.

6. LAU W.Y., LEUNG K. L., ZHU X. L., LAM Y.H., CHUNG S.C.S., LI A.K.C. Laparoscopic repair of perforated peptic ulcer. Br J Surg, 1995, 82: 814-16.

7. BERGAMASHI R., MARVIK R., JOHNSEN G., THORESEN J. E.K., YSTGAARD B., MYRVOLD H.E. Open vs laparoscopic repair of perforated peptic ulcer. Surg Endoscope, 1999, 13: 679-82.

8. SVANES C., SALVESEN H., STANGELAND L., SVANES K., SOREIDE O. Perforated peptic ulcer over 56 years. Time trends in patients and disease characteristics. Gut, 1993, 34: 1666-71.

9. CHEN C.H., HUANG H.S., YANG C.C., YEH Y.H. The features of perforated peptic ulcers in conventional computed tomography. Hepatogastro-enterology, 2001, 48: 1393-96.

10. BLEOCHLE C., EMMERMANN A., TREU H., ACHILLES E., MACK D., ZORING C., BROELSCH C.E. The effect of a pneumoperitoneum on the extent and severity of peritonitis induced by gastric ulcer perforation in the rat. Surg Endose, 1995, $9: 898-901$. 